\title{
Comparison of Fluoride Ion Release from Fluoride Gel in Various Solvents
}

\section{Usporedba otpuštanja iona fluora iz fluoridnih gelova u različitim otapalima}

\author{
${ }^{1}$ University of Zagreb, School of Dental Medicine Croatia \\ Stomatološki fakultet Sveučilišta u Zagrebu, Hrvatska \\ 2 Department of Pharmacology, School of Dental Medicine University of Zagreb, Croatia \\ Katedra za farmakologiju Stomatološkog fakulteta Sveučilišta u Zagrebu, Hrvatska
}

Received: April 23, 2020

Accepted: June 1, 2020

Address for correspondence

Peros Kristina PhD DMD,

University of Zagreb, School of Dental

Medicine

Department of Pharmacology

Šalata 11, 10000 Zagreb, Croatia, phone: +38514566957 ,

fax: +38514920049

peros@sfzg.hr

Key words

Cariostatic Agents; Topical Fluorides; Gels; Sodium Fluoride; Ion-selective Electrodes; Amine Fluoride

\section{Introduction}

High concentration fluoride gels are used for caries prevention and therapy (1). A variety of fluoride compounds (e.g. sodium fluoride, amine fluoride, stannous fluoride, silane fluoride) are used as topical prophylaxis agents, however, all of them must meet one basic requirement - fluoride ion liberation. It is considered important for fluoride ion concentration to be even slightly increased in the proximity of the tooth surface for the remineralization to be effective $(2,3,4)$.

Sodium fluoride, an inorganic and very soluble salt, liberates $\mathrm{F}^{-}$ions readily and its effectiveness has been proven many times. Amine fluorides, on the other hand, contain covalently bonded fluorine. Amphipathic character advantages them to stay in contact with the tooth surface during longer periods. The available data of research are unclear in regard to superiority of one of them in remineralization, but both compoun$\mathrm{ds}$ are proven effective in caries prevention (5). Since fluoride ions are very reactive, they become ineffective easily. Eggert and Neubert investigated the liberation of fluoride ions from toothpastes and concluded that fluoride ion release is modified depending on auxiliaries present in the product (6).
Uvod

Fluoridni gelovi u visokoj koncentraciji upotrebljavaju se za prevenciju i terapiju karijesa (1). Različiti fluoridni spojevi (npr. natrijev fluorid, aminofluorid, kositreni fluorid, silan-fluorid) upotrebljavaju se za topikalnu profilaksu, no svi moraju zadovoljiti jedan osnovni zahtjev - osloboditi fluoride. Održavanje čak i malo povišene koncentracije fluoridnih (F) iona u blizini površine zuba smatra se važnim kako bi remineralizacija bila učinkovita $(2,3,4)$.

Natrijev fluorid, anorganska i dobro topljiva sol, lagano oslobađa $\mathrm{F}^{-}$ione i njegova je učinkovitost mnogo puta dokazana. Aminofluoridi, pak, sadržavaju kovalentno vezani fluor. Amfipatično svojstvo omogućuje im da dulje ostanu u kontaktu s površinom zuba. Podatci dostupni u literaturi ne govore u prilog superiornosti jednoga od njih u remineralizaciji, ali oba su spoja dokazano učinkovita u prevenciji karijesa (5). Budući da su fluoridni ioni vrlo reaktivni, lako postaju neučinkoviti. Eggert i Neubert istraživali su oslobađanje fluorida iz pasta za zube i zaključili su da se oslobađanje fluorida iona mijenja ovisno o pomoćnim sastojcima u proizvodu (6). 
Topical fluorides are of great importance for cancer patients treated with radiation therapy in the region of head and neck. Irradiated salivary glands deteriorate in function leading to dry mouth, changes in oral environment and radiation caries. A failure in excellent oral hygiene maintenance and topical fluoridation regime leads to rampant caries development $(7,8,9)$. Caries can be successfully prevented if high concentration fluoride gels are used in custom trays. Fluoridation protocols are proposed for facilitating the use. $\mathrm{Za}$ ndim et al. recommended the use of a $0.025 \% \mathrm{NaF}$ mouth rinse together with artificial saliva for radiation-induced hyposalivation patients, and Abdalla et al. recommended a mouth rinse containing $0.05 \% \mathrm{NaF}$ and $0.12 \%$ chlorhexidine-gluconate twice-a day $(10,11)$. The latter combination of fluorides and antimicrobial agent might be more effective due to their effect both on the demineralization-remineralization process and oral microbes as found by Abdalla et al (11). The aim of this study was to determine the concentration of free fluoride ions, using solutions which may be used for xerostomia therapy that served us as solvents - in order that fluoride ion interactions can be assessed as a first step for further investigation of alternative topical fluoridation protocols.

The null hypothesis was that there is no difference in $\mathrm{F}^{-}$ ions release from various fluoride gels in different solvents, therefore, there is no deviation from the label amount of $\mathrm{F}$ ion concentration.

\section{Material and methods}

\section{Study samples selection}

Two fluoride gels containing different active ingredients were used in this study. The information about the products is presented in Table 1 .

Five different solvents were used: distilled water (Iskra d.d., Sv. Ivan Zelina, Croatia), redistilled water (the institution), tap water (the institution), $0.9 \%$ sodium chloride solution - saline (Natrii chloridi infundibile Pliva, Pliva Hrvatska d.o.o., Zagreb, Croatia) and artificial saliva Axerosta ${ }^{\mathrm{r}}$ (Mages Plant Sp. zo.o., Warsaw, Poland)

The samples were measured with the analytical balance ABS 80-4N (Kern \& Sohn GmbH, Balingen, Germany) and the automatic pipette Eppendorf Research ${ }^{\mathrm{r}}$ (Eppendorf, Hamburg, Germany) in polystyrene vials (Ratiolab, Germany).

The measuring electrode used was the fluoride-selective electrode type 96 - 09 (Thermo Scientific, Waltham, Massachusetts, USA) with the microprocessor analyzer ORION EA 940 (Orion Research Inc., USA). Samples were stirred at $500 \mathrm{rpm}$ on the magnetic stir plate (IKA-Werke GmbH \& Co. KG, Staufen, Germany) during the entire measuring process.

\section{Fluoride concentration measurements}

The international standard ISO 19448 was used as a reference for the methodology (12).

Fluoride gels and solvents are left at the room temperature. To achieve the product homogeneity, a bottle of sodium
Topikalni fluoridi vrlo su važni za pacijente s malignom bolešću ako su liječeni zračenjem u području glave i vrata. Naime, ozračene žlijezde slinovnice gube svoju funkciju, što rezultira suhoćom usta, promjenama u oralnom okolišu i radijacijskim karijesom. Neuspjeh u izvrsnom održavanju oralne higijene i topikalnom režimu fluoridacije potiče pojavu opsežnih karijesnih lezija $(7,8,9)$. To posljednje može se uspješno spriječiti ako se u individualnim udlagama primjenjuju fluoridni gelovi s visokim koncentracijama fluorida. Predloženi su jednostavniji protokoli za topikalnu fluoridaciju. Zandim i suradnici preporučili su korišstenje 0,025-postotne $\mathrm{NaF}$ otopine za ispiranje usta zajedno s umjetnom slinom za bolesnike $s$ hiposalivacijom induciranom zračenjem, a Abdalla i suradnici savjetovali su ispiranje usta otopinom koja sadržava $0,05 \%$ natrijeva fluorida i $0,12 \%$ klorheksidin-glukonata dva puta na dan $(10,11)$. Kombinacija fluorida i antimikrobnog sredstva može biti učinkovitija zbog utjecaja i na demineralizacijsko-remineralizacijski proces i oralne mikrobe, kako su opisali Abdalla i suradnici (11).

Cilj ovog istraživanja bio je odrediti koncentraciju slobodnih fluoridnih iona u otopinama koje bi se mogle upotrijebiti u terapiji kserostomije, a koja su nam poslužila kao otapala kako bi se dobio uvid u ionske interakcije fluorida, što je prvi korak u daljnjem istraživanju alternativnih protokola topikalne fluoridacije.

Nulta hipoteza glasila je da nema razlike u otpuštanju Fiona iz različitih fluoridnih gelova u različitim otapalima te da zato nema odstupanja od deklarirane koncentracije $\mathrm{F}$ - iona.

\section{Materijali i metode}

\section{Odabir uzoraka}

U ovom istraživanju korištena su dva fluoridna gela koja sadržavaju različite aktivne sastojke. Informacije o proizvodima nalaze se u tablici 1 .

Korišteno je pet različitih otapala: destilirana voda (Iskra d.d., Sv. Ivan Zelina, Hrvatska), redestilirana voda (instituci$j a$ ), voda iz slavine (institucija), 0,9-postotna otopina natrijeva klorida - fiziološka otopina (Natrii chloriin infundibile Pliva, Hrvatska d.o.o., Zagreb, Hrvatska) i umjetna slina Axerosta ${ }^{\mathrm{r}}$ (Mages Plant Sp. zo.o., Poljska).

Uzorci su izmjereni analitičkom vagom ABS 80-4N (Kern \& Sohn GmbH, Balingen, Njemačka) i automatskom pipetom Eppendorf Research ${ }^{\mathrm{r}}$ (Eppendorf, Hamburg, Njemačka) u polistirenskim čašicama (Ratiolab, Njemačka).).

Korištena mjerna elektroda bila je fluorno-selektivna elektroda tipa 96-09 (Thermo Scientific, Waltham, Massachusetts, $S A D$ ) $s$ analizatorom ORION EA 940 (Orion Research $I n c$., $S A D$ ). Tijekom cijelog mjernog procesa uzroci su miješani u magnetskoj miješalici (IKA-Werke GmbH \& Co. KG, Staufen, Njemačka) brzinom od $500 \mathrm{rpm}$.

\section{Mjerenje koncentracije fluorida}

Međunarodna norma ISO 19448 korištena je kao referencija za metodologiju mjerenja (12).

Fluoridni gelovi i otapala ostavljeni su na sobnoj temperaturi. Prije njihova otvaranja, kako bi se osigurala homoge- 


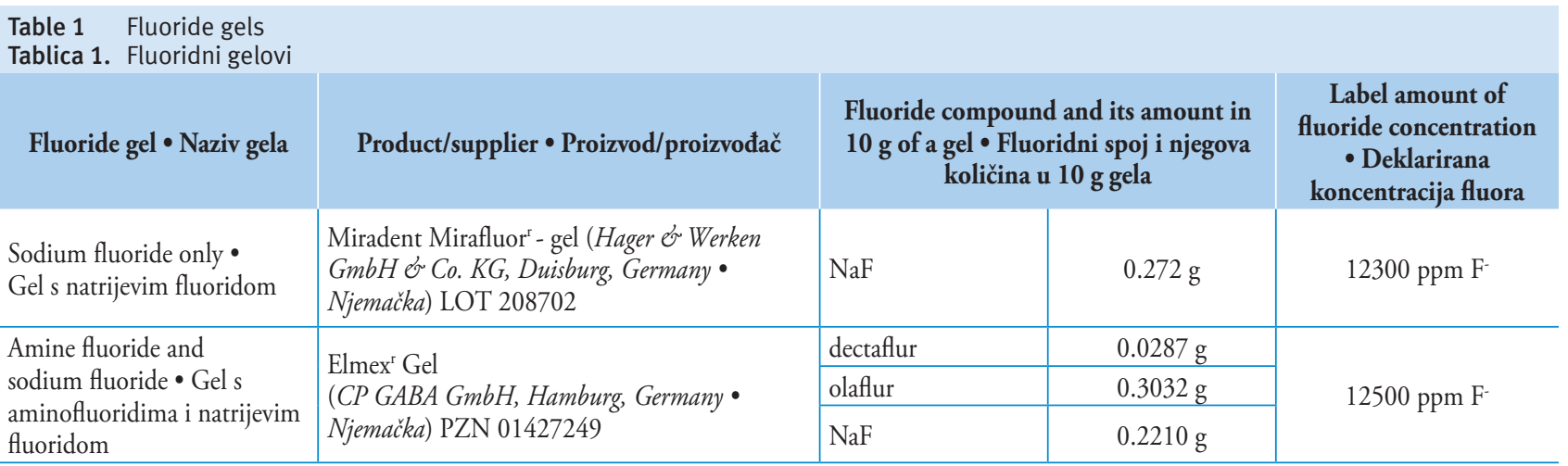

fluoride only was shaken and the gel tube containing amine fluoride and sodium fluoride was kneaded prior to opening. Subsequently, $1 \mathrm{~cm}$ of each product was dispensed and discarded. The samples were obtained from the remaining product.

Five samples were prepared from each fluoride gel to be dissolved in five different solvents. A polystyrene vial was placed on a balance and the balance was tarred. $0.055 \mathrm{~g}$ of the gel product was then added to the vial. Distilled water, redistilled water, tap water and saline solution were added to each particular vial with automatic pipette in volume of 5.5 $\mathrm{ml}$. The artificial saliva product was difficult to pipette due to its viscosity. Therefore, the vial containing fluoride gel sample was placed on the balance and the artificial saliva product was added to the vial to the total mass of $5.555 \mathrm{~g}$.

The direct analysis technique was used to determine the amount of fluoride ion concentration.

Prior to the analysis of the solutions, the accuracy of the measuring instrument was checked as well as the electrode inclination according to the manufacturer's instructions. After that, the measuring instrument was calibrated at room temperature over the range of $19 \mathrm{ppm} \mathrm{F}^{-}$to $190 \mathrm{ppm} \mathrm{F}^{-}$.

Each vial containing the sample was placed on the magnetic stir plate and the magnetic stir bar was added, then the fluoride-selective electrode was immersed in the solution. For each sample 10 measurements were performed and expressed in $\mathrm{mgF} / \mathrm{l}$ (ppm F).

Prior to measuring $\mathrm{F}^{-}$ion concentrations in pure solvents, the measuring instrument was once more calibrated at room temperature over the range of $0.19 \mathrm{ppm} \mathrm{F}^{-}$to $1.9 \mathrm{ppm} \mathrm{F}^{-}$.

The direct analysis technique was used as has already been described in the previous paragraph.

\section{Statistical analysis}

Since $0.055 \mathrm{~g}$ of fluoride gel was dissolved in $5.5 \mathrm{ml}$ of solvent, the dilution factor was 100 . Therefore, all the measured values were multiplied by 100 prior to the statistical analysis.

Descriptive statistics were used and a paired two-sample for means t-test was used to determine if there were significant differences between the measured fluoride concentration and the concentration value listed on the label.

The ANOVA was used to determine if there were significant differences between the liberation of fluoride ions from each gel in each particular solvent.

Furthermore, the ANOVA was used to determine if there were significant differences between the liberation of fluori- nost proizvoda, bočica $\mathrm{NaF}$ gela je promućkana, a tuba gela s NaF-om i aminofluoridima je gnječena. Zatim se iz svakog pakiranja istisnuo i odbacio $1 \mathrm{~cm}$ gela, a uzorci za mjerenje pripravljeni su od ostatka sadržaja u tubi.

Pripremljeno je pet uzoraka od svakoga gela kako bi se otopili u pet različitih otapala. Polistirenska čašica stavljena je na vagu i vaga je tarirana. $U$ čašicu je zatim dodano $0,055 \mathrm{~g}$ gela. Zatim su u svaku polistirensku čašicu dodane destilirana voda, redestilirana voda, voda iz slavine i fiziološka otopina automatskim pipetom u volumenu od $5,5 \mathrm{ml}$. Zbog velike viskoznosti preparata umjetne sline, pipetiranje je bilo otežano. Zato je čašica s uzorkom fluoridnog gela postavljena na analitičku vagu i u nju je pipetom dodan preparat umjetne sline do ukupne mase uzorka od 5,555 g.

Izravna metoda mjerenja korištena je za određivanje količine koncentracije fluorida iona.

Prije analize uzoraka provjereni su ispravnost i nagib elektrode prema uputi proizvođača, a zatim je uređaj kalibriran pri sobnoj temperaturi za mjerenje koncentracija u rasponu od 19 ppm F- do 190 ppm F-.

Svaka čašica s uzorkom postavljena je na magnetsku miješalicu i dodan je štapić za miješanje, a zatim je fluor-selektivna elektroda uronjena u otopinu. Za svaki uzorak učinjeno je deset očitanja koncentracije i vrijednosti koncentracije izražene su u mgF/l (ppm F').

Prije analize koncentracije $\mathrm{F}^{-}$iona u čistim otapalima, fluor-selektivna elektroda ponovno je kalibrirana za mjerenje koncentracija u rasponu od 0,19 ppm F- do 1,9 ppm F-.

Primijenjena je tehnika izravne analize, kao što je već opisano.

\section{Statistička analiza}

Budući da je 0,055 g fluoridnog gela otopljeno u 5,5 ml otapala, analizirani uzorci fluoridnih gelova bili su razrijeđeni 100 puta. Zato su prije analize i obrade podataka sve očitane vrijednosti pomnožene s korekcijskim faktorom 100 .

Podatci su obrađeni metodama deskriptivne statistike, a za utvrđivanje postoji li značajna razlika između deklarirane i izmjerene koncentracije fluorida korišten je t-test za male zavisne uzorke. Za utvrđivanje razlika u otpuštanju $\mathrm{F}^{-}$iona iz pojedinog gela u svakom otapalu korištena je ANOVA. Za utvrđivanje postoji li razlika u otpuštanju $\mathrm{F}^{-}$iona između $\mathrm{NaF}$ gela i gela koji sadržava $\mathrm{NaF}$ i aminofluoride u istim otapalima, korišten je također ANOVA test. 
de ions from sodium fluoride only gel and the gel containing amine fluoride and sodium fluoride in the same solvents.

ThePost hoc Tukey's test was used for multiple comparisons between each of the solutions.

The significance level for all tests was $\alpha=5 \%$.

\section{Results}

$\mathrm{F}^{-}$ion concentrations measured in pure solvents are presented in Table 2.

Mean measured concentrations of fluoride ions in solutions of gel are presented in Tables 3 and 4.

A statistically significant difference between the measured fluoride concentration and the concentration value listed on the label was determined both for sodium fluoride only gel and gel containing amine fluoride and sodium fluoride by the use of a paired two-sample for means t-test.

Furthermore, the results suggested that there were some differences in the liberation of fluoride ions in different solvents. The Post hoc Tukey's test was then used to determine individual differences in the liberation of fluoride ions from each gel in each particular solvent. There was a significant difference in fluoride ion release in every sodium fluoride only gel solution. However, there was not a significant difference between distilled and redistilled water solutions. Fluo-
Post hoc Tukeyev test korišten je za višestruku usporedbu između pojedinih otopina.

Razina značajnosti za sve testove bila je $\alpha=5 \%$.

\section{Rezultati}

Koncentracije $\mathrm{F}^{-}$iona izmjerene u čistim otapalima prikazane su u tablici 2.

Srednje vrijednosti izmjerene koncentracije fluorida $u$ otopinama gelova prikazane su u tablicama 3 i 4 .

Statistički značajna razlika između izmjerenih i deklariranih koncentracija fluorida i u NaF gelu i gelu koji sadržava aminofluoride i $\mathrm{NaF}$ utvrđena je t-testom.

Nadalje, rezultati su upućivali na razlike u oslobađanju fluorida u različitim otapalima. Post hoc Tukeyjev test korišten je za određivanje pojedinačnih razlika u oslobađanju fluoridnih iona iz svakoga gela u svakom otapalu. Značajna razlika u otpuštanju fluorida iz $\mathrm{NaF}$ gela utvrđena je u svakoj otopini, osim između otopina destilirane i redestilirane vode. Oslobađanje fluoridnih iona bilo je značajno različito u svakoj otopini gela koji sadržava aminofluoride i natrijev fluorid, osim između otopina destilirane i redestilirane vode te između otopine redestilirane vode i otopine umjetne sline.

Table $2 \quad F$ - ion concentration in pure solvents

Tablica 2. Koncentracija F- iona u čistim otapalima

\begin{tabular}{l|c}
\multicolumn{1}{c}{ Solvent $\bullet$ Otapalo } & $\begin{array}{c}\text { F- ion concentration mean value } \pm \text { SD [ppm F- }] \bullet \\
\text { Koncentracija F- iona srednja vrijednost } \pm \text { SD [ppm F- }]\end{array}$ \\
\hline Distilled water $\bullet$ Destilirana voda & $0.0206 \pm 0.0070$ \\
\hline Redistilled water $\bullet$ Redestilirana voda & $0.0027 \pm 0.0019$ \\
\hline Tap water $\bullet$ Voda iz slavine & $0.2595 \pm 0.1140$ \\
\hline Saline solution $\bullet$ Fiziološka otopina & $0.0023 \pm 0.0006$ \\
\hline Axerosta $^{\mathrm{r}}$ & $0.0629 \pm 0.0059$ \\
\hline
\end{tabular}

Table 3 F ion concentration in sodium fluoride only solutions Tablica 3. Koncentracija F-iona u otopinama natrijeva fluorida

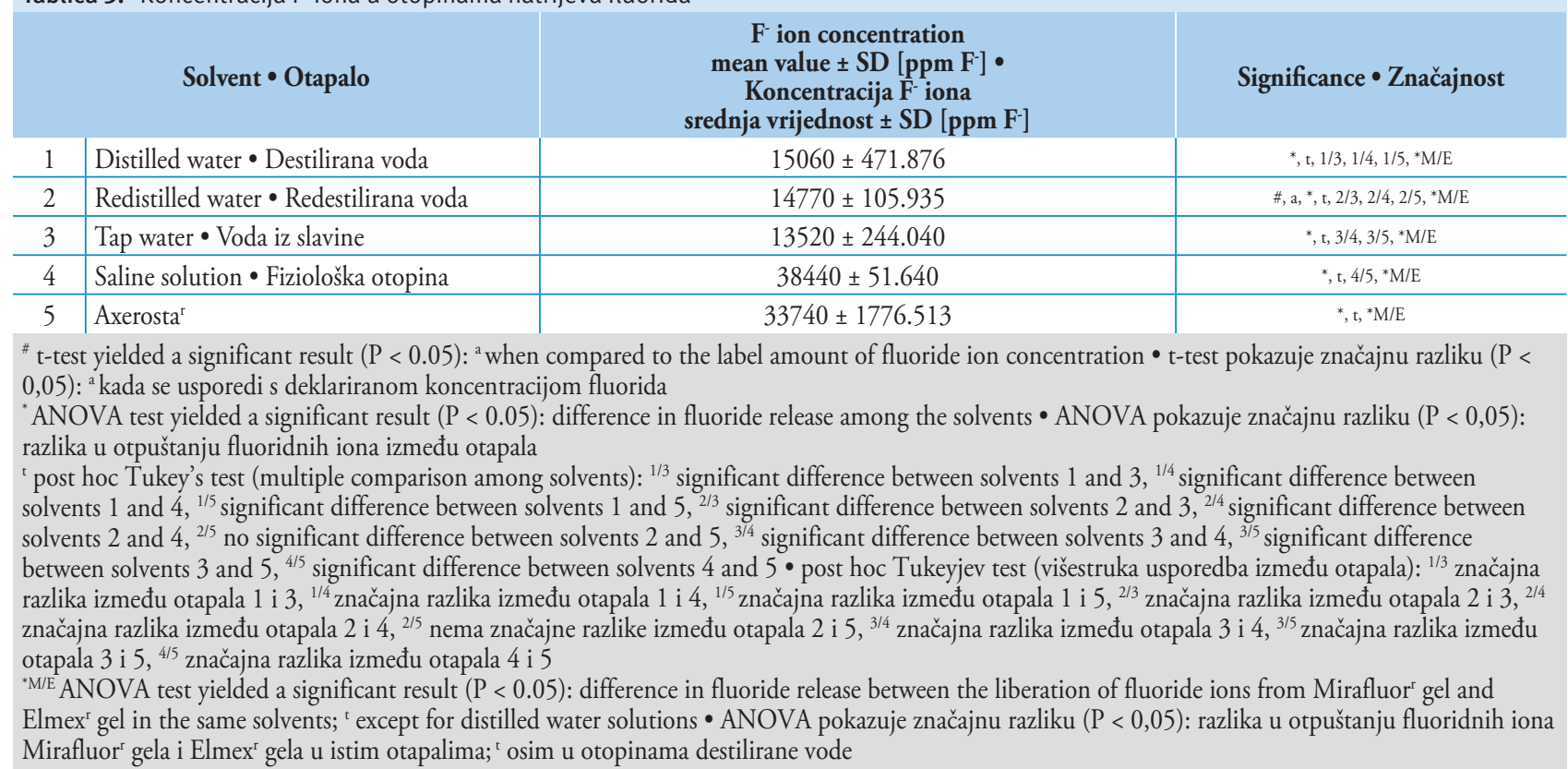


Table $4 \quad F$ ion concentration in gel containing amine fluoride and sodium fluoride solutions

Tablica 4. Koncentracija F- iona u otopinama gela koji sadržava i aminofluoride i natrijev fluorid

\begin{tabular}{|c|c|c|c|}
\hline \multicolumn{2}{|r|}{ Solvent $\bullet$ Otapalo } & \multirow{2}{*}{ 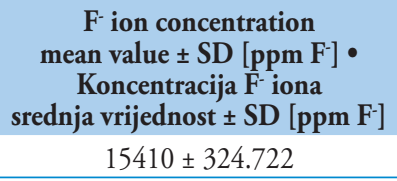 } & \multirow{2}{*}{$\begin{array}{c}\text { Significance } \bullet \text { Značajnost } \\
{ }^{*}, \mathrm{t}, 1 / 3,1 / 4,1 / 5,{ }^{*} \mathrm{M} / \mathrm{E}\end{array}$} \\
\hline 1 & Distilled water $\bullet$ Destilirana voda & & \\
\hline 2 & Redistilled water $\bullet$ Redestilirana voda & $16110 \pm 331.495$ & $\#, \mathrm{a},{ }^{*}, \mathrm{t}, 2 / 3,2 / 4,2 / 5,{ }^{*} \mathrm{M} / \mathrm{E}$ \\
\hline 3 & Tap water $\bullet$ Voda iz slavine & $7892 \pm 342.436$ & ${ }^{*}, \mathrm{t}, 3 / 4,3 / 5,{ }^{*} \mathrm{M} / \mathrm{E}$ \\
\hline 5 & Axerosta $^{r}$ & $16690 \pm 1581.455$ & ${ }^{*}, \mathrm{t},{ }^{*} \mathrm{M} / \mathrm{E}$ \\
\hline
\end{tabular}

${ }^{\#} \mathrm{t}$-test yielded a significant result $(\mathrm{P}<0.05)$ : ${ }^{a}$ when compared to the label amount of fluoride ion concentration $\bullet \mathrm{t}$-test pokazuje značajnu razliku $(\mathrm{P}<$ $0,05):{ }^{a}$ kada se usporedi $s$ deklariranom koncentracijom fluorida

"ANOVA test yielded a significant result $(\mathrm{P}<0.05)$ : difference in fluoride release among the solvents $\bullet$ ANOVA pokazuje značajnu razliku $(\mathrm{P}<0,05)$ : razlika u otpuštanju fluoridnih iona između otapala

' post hoc Tukey's test (multiple comparison among solvents): ${ }^{1 / 3}$ significant difference between solvents 1 and $3,{ }^{1 / 4}$ significant difference between solvents 1 and 4, ${ }^{1 / 5}$ significant difference between solvents 1 and $5,{ }^{2 / 3}$ significant difference between solvents 2 and $3{ }^{2 / 4}$ significant difference between solvents 2 and $4,{ }^{2 / 5}$ no significant difference between solvents 2 and $5,{ }^{3 / 4}$ significant difference between solvents 3 and $4,{ }^{3 / 5}$ significant difference between solvents 3 and $5,{ }^{4 / 5}$ significant difference between solvents 4 and $5 \bullet$ post hoc Tukeyev test (višestruka usporedba između otapala): ${ }^{1 / 3}$ značajna razlika između otapala 1 i $3,{ }^{1 / 4}$ značajna razlika između otapala 1 i $4,{ }^{1 / 5}$ značajna razlika između otapala 1 i $5,{ }^{2 / 3}$ značajna razlika između otapala 2 i $3,{ }^{2 / 4}$ značajna razlika između otapala 2 i $4,{ }^{2 / 5}$ nema značajne razlika između otapala 2 i $5,{ }^{3 / 4}$ značajna razlika između otapala 3 i $4,{ }^{3 / 5}$ značajna razlika između otapala 3 i $5,{ }^{4 / 5}$ značajna razlika između otapala 4 i 5

${ }^{*} \mathrm{M} / \mathrm{E}$ ANOVA test yielded a significant result $(\mathrm{P}<0.05)$ : difference in fluoride release between the liberation of fluoride ions from Mirafluor ${ }^{\mathrm{r}}$ gel and Elmex ${ }^{\mathrm{r}}$ gel in the same solvents; ${ }^{\mathrm{t}}$ except for distilled water solutions $\bullet$ ANOVA pokazuje značajnu razliku $(\mathrm{P}<0,05)$ : razlika u otpuštanju fluoridnih iona Mirafluor ${ }^{\mathrm{r}}$ gela i Elmex ${ }^{\mathrm{r}}$ gela u istim otapalima; ${ }^{\mathrm{t}}$ osim u otopinama destilirane vode

ride ion release was significantly different in every solution of gel containing amine fluoride and sodium fluoride except between distilled and redistilled water solutions and between redistilled water and artificial saliva solutions.

The ANOVA showed statistically significant differences between the liberation of fluoride ions from sodium fluoride only gel and gel containing amine fluoride and sodium fluoride in the same solvents. The Post hoc Tukey's test revealed that significant differences exist between all the solvents except for distilled water.

\section{Discussion}

In clinical situations it is necessary to recommend reliable therapies with predictable and consistent outcomes. Therefore, it is important to have insight into possible chemical interactions which may influence the effectiveness of topical fluorides (13).

Cate et al. proved that the remineralization of advanced enamel lesions benefits from more concentrated fluoride treatment (14). Therefore, the first step was to determine whether the label amount of fluorides corresponded with the readily available $\mathrm{F}^{-}$ions in fluoride gels. Depending on which fluoride compound is added to a dentifrice and which fluoride fraction is measured, various analytical methods can be used (15). The results suggest that there is a difference between the measured fluoride concentration and the concentration value listed on the label both for sodium fluoride only and the gel containing amine fluoride and sodium fluoride. However, in this study, it has been determined that concentrations of $\mathrm{F}^{-}$ ions in redistilled water were higher than the label amount of fluoride ion concentration in both gels, sodium fluoride and amine fluoride gel, which indicates that all the fluoride compounds form both gels dissolved entirely. $\mathrm{F}^{-}$ion concentrations in pure solvent samples, in this study, were negligibly low
ANOVA je pokazala statistički značajne razlike između oslobađanja fluorida iz NaF gela i gela koji sadržava aminofluoride i $\mathrm{NaF} u$ istim otapalima. Post hoc Tukeyjev test pokazao je da postoje značajne razlike između svih otapala, osim destilirane vode.

\section{Rasprava}

U kliničkoj praksi potrebno je preporučiti pouzdane terapije s predvidivim i pouzdanim ishodima. Zato je važno imati uvid u moguće kemijske interakcije koje mogu utjecati na učinkovitost topikalnih fluorida (13).

Cate i suradnici dokazali su je da remineralizacija naprednih karijesnih lezija cakline poboljšana u otopinama $s$ višim koncentracijama fluorida (14). Zato je prvi korak bio ustanoviti odgovara li deklarirana koncentracija fluorida koncentraciji slobodnih $\mathrm{F}^{-}$iona u fluoridnim gelovima. Ovisno o tomu koji je fluoridni spoj dodan pojedinom gelu i koja se frakcija fluorida želi mjeriti, primjenjuju se različite analitičke metode (15). Rezultati pokazuju da postoji razlika između izmjerene koncentracije fluorida i deklarirane koncentracije za gel samo s natrijevim fluoridom i gel koji sadržava i aminofluoride i natrijev fluorid. No u ovom istraživanju utvrđeno je da su koncentracije $\mathrm{F}^{-}$iona u redestiliranoj vodi veće od deklariranih za otopine obaju gelova, što upućuje na to da su svi spojevi fluorida potpuno otopljeni. F- koncentracije iona u uzorcima čistog otapala, u ovom ispitivanju, bile su iznimno niske i nisu mogle povećati koncentracije $\mathrm{F}^{-}$iona u otopinama fluoridnih gelova. Koncentracija fluorida izmjerena u vodi iz slavine odgovara već objavljenim podatcima (16). 
and could not increase $\mathrm{F}^{-}$ion concentrations in fluoride gels solutions. Fluoride ion concentration measured in tap water corresponded to the previously published data (16).

The measured higher concentrations might be a repercussion of Total Ionic Strength Adjustment Buffer (TISAB) (which is prescribed by ISO 19448:2018 standard) not being added to the tested solutions. When fluoride-selective electrode is used, different buffers can be utilized. Those buffers modify the electrode sensitivity and measurement precision (17). The TISAB was not used in this study because only ion interactions in various solvents can be observed.

The results showed that there was a significant difference in the fluoride ion liberation from fluoride gels in various solvents.

Fluoride ion concentration in sodium fluoride only and tap water solution was significantly lower than concentration measured in solution of sodium fluoride in distilled and redistilled water. Tap water contains various ions dissolved which interact with $\mathrm{F}^{-}$ions. Calcium ions bind $\mathrm{F}^{-}$ions and tap water contains high amount of calcium ions (16). On the other hand, significantly higher fluoride ion concentration was measured in the solution of sodium fluoride only gel in saline than in other sodium fluoride only solutions. Martinez-Mier et al. investigated the methods for measurements of fluoride ions in table salt and possible interferences of the presence of $\mathrm{NaCl}$ and other ions in the salt with the measurement of fluoride ions by use of fluoride-selective electrode (18). In their study, their results obtained using $\mathrm{F}$ standards with $\mathrm{NaCl}$ added produced an overall $10 \%$ increase in fluoride ion values. Since saline solution contains sodium chloride, $\mathrm{Cl}^{-}$ions could interact with $\mathrm{Na}^{+}$ions from $\mathrm{NaF}$ and make more $\mathrm{F}^{-}$ions free. Furthermore, $\mathrm{F}^{-}$ion concentration measured in the solution of sodium fluoride only gel in artificial saliva was higher than those in all the other sodium fluoride only solution except for the one in saline. The artificial saliva product, according to the label, contains citrates and acetates. According to several studies, citrates liberate fluorides from complex ions (19). Acetates, which are part of TISAB, are also responsible for the liberation of $\mathrm{F}^{-}$ions $(20,21)$. The aim of this study was not to argue about bioavailability of sodium fluoride in saline and artificial saliva solutions, but this study can be a starting point for further studies.

The gel containing amine fluoride and sodium fluoride contains amine fluorides in a greater amount than $\mathrm{NaF}$. Covalently bonded fluorine in amine fluorides does not dissociate in the same manner as the ionic one from $\mathrm{NaF}$. When observed isolated, the differences in solutions of gel containing amine fluoride and sodium fluoride are observed between all the solutions.

The concentrations of fluoride ions in the solution of gel containing amine fluoride and sodium fluoride in tap water are significantly lower than those of the same gel in other solvents. According to Table 4 and Table 1, the measured concentration of $\mathrm{F}^{-}$ions in tap water solution of gel containing amine fluoride and sodium fluoride corresponds to the amount of amine fluorides in the gel product. As described in the previous paragraph, different ions (primarily $\mathrm{Ca}^{2+}$ ions) present in tap water interacted with $\mathrm{NaF}$, which resulted in lower concentration being measured.
Izmjerene veće koncentracije mogu biti posljedica nekorištenja puferskog sustava Total Ionic Strength Adjustment Buffer (TISAB) (propisan je normom ISO 19448:2018) u ispitivanim otopinama. Kada se upotrebljava fluorid-selektivna elektroda, mogu poslužiti različiti puferi. Puferi mijenjaju osjetljivost elektrode i preciznost mjerenja (17). TISAB se nije koristio u ovom ispitivanju kako bi se procijenile isključivo interakcije iona u različitim otapalima.

Rezultati su pokazali da postoji značajna razlika u otpuštanju fluoridnih iona iz fluoridnih gelova u različitim otapalima.

Koncentracija fluoridnih iona u otopini gela koji sadržava samo natrijev fluorid $i$ vode iz slavine bila je značajno niža od koncentracije izmjerene u otopini $\mathrm{NaF}$ gela u destiliranoj i redestiliranoj vodi. Voda iz slavine sadržava različite otopljene ione koji ulaze u interakciju s $\mathrm{F}^{-}$ionima. Kalcijev ioni vežu F- ione, a voda iz slavine sadržava veliku količinu kalcijevih iona (16). S druge strane, značajno veća koncentracija fluoridnih iona izmjerena je u otopini gela s natrijevim fluoridom u fiziološkoj otopini, negoli u drugim otopinama istoga gela. Martinez-Mier i suradnici istraživali su metode mjerenju fluorida u kuhinjskoj soli i moguće poteškoće pri mjerenja fluor-selektivnom elektrodom zbog prisutnosti $\mathrm{NaCl}$-a i drugih iona u kuhinjskoj soli (18). U njihovu istraživanju, korištenjem F standarda s dodanim $\mathrm{NaCl}$-om, izmjerene su $10 \%$ veće vrijednosti fluoridnih iona. Budući da fiziološka otopina sadržava natrijev klorid, $\mathrm{Cl}^{-}$ioni ulaze u interakciju s $\mathrm{Na}^{+}$ionima iz NaF-a i oslobađaju više F- iona. Nadalje, koncentracija $\mathrm{F}^{-}$iona izmjerena u otopini $\mathrm{NaF}$ gela u umjetnoj slini bila je veća od one u svim ostalim otopinama $\mathrm{NaF}$ gela, osim u fiziološkoj otopini. Preparat umjetne sline, prema deklaraciji, sadržava citrate i acetate. Prema podatcima iz nekoliko istraživanja, citrati oslobađaju fluoride iz ionskih kompleksa (19). Acetati, koji su dio TISAB-a, također su odgovorni za oslobađanje $\mathrm{F}^{-}$iona $(20,21)$. Unatoč tomu, $\mathrm{u}$ ovom se istraživanju ne može raspravljati o bioraspoloživosti natrijeva fluorida u fiziološkoj otopini i otopini umjetne sline, ali može biti polazište za daljnja istraživanja.

Gel u kojem su aminofluoridi i natrijev fluorid sadržava aminofluoride u većoj količini od $\mathrm{NaF}-\mathrm{a}$. Kovalentno vezani fluor u aminofluoridima ne disocira na isti način kao ionski fluor iz NaF-a. Kada se promatraju izolirano, razlike u otopinama gela koji sadržavaju i aminofluoride i natrijev fluorid postoje između svih otopina.

Koncentracije fluorida u otopini gela koji sadržavaju i aminofluoride i natrijev fluorid $\mathrm{u}$ vodi iz slavine znatno su niže od onih istoga gela u drugim otapalima. Prema tablici 4 . i tablici 1., izmjerena koncentracija $\mathrm{F}^{-}$iona u otopini gela koji sadržava i aminofluoride i natrijev fluorid u vodi iz slavine, odgovara količini aminofluorida u gelu. Kao što je opisano u gornjem odlomku, različiti ioni (ponajprije $\mathrm{Ca}^{2+}$ ioni) u vodi iz slavine u interakciji su s $\mathrm{NaF}-o m$, što je rezultiralo mjerenjem niže koncentracije.

Kada se otopine gela koji sadržava i aminofluoride i natrijev fluorid uspoređuju s otopinama $\mathrm{NaF}$ gela, potvrdila se stabilnost aminofluorida. Koncentracije F- iona u otopinama gela $s$ aminofluoridima i NaF-om u fiziološkoj otopini i umjetnoj slini razlikuju se, ali su mnogo bliže otopini toga 
When solutions of the gel containing amine fluoride and sodium fluoride are compared with sodium fluoride only solutions, the stability of amine fluorides is verified. F-ion concentrations in saline and artificial saliva solutions of gel containing amine fluoride and sodium fluoride differ but are much closer to the redistilled water solution of that gel. Those concentrations are almost three times lower than $\mathrm{F}^{-}$concentration in the solutions of sodium fluoride only in the same solvents due to lack of ion interactions between amine fluorides and other ions present in the solutions.

The limitations of this analysis relate to the sample and analysis methods.

The analysis methods were based on a relatively new ISO 19448:2018 standard. ISO 19448:2018 standard was supposed to be a generic guideline, which does not make a distinction between fluoride compounds. The method should be acceptable for the analysis of fluoride in aqueous samples derived from all fluoridated dental products.

We made a modification to the ISO 19448:2018 standard and did not add TISAB to the solutions, which might have influenced the measurement, as mentioned earlier.

In the absence of an additional, well-established, method of analysis being used on the same samples (i.e. liquid gas chromatography (22)) it is not possible to completely asses the validity of the ISO 19448:2018 standard.

The study used a small, non-systematic convenience sample of fluoride gels, using only one sample of each type.

Without reliable and comprehensive guidelines on the composition of fluoride gels, it is not possible to extrapolate effectiveness of the gels based on the fluoride content. However, this study observed ionic interactions, which might affect the demineralization-remineralization process in vivo.

\section{Conclusion}

Sodium fluoride and amine fluorides differ in fluoride ion delivery mechanisms. Amine fluorides do not interact with other ions present in the solution, whereas $\mathrm{F}^{-}$ion release from sodium fluoride alters when other ions are dissolved in the same solution. Furthermore, the greater amount of $\mathrm{F}^{-}$ions is released from $\mathrm{NaF}$ in the solutions which contain chlorides, citrates and acetates. Given that, it should be noted that amine fluorides are more stable compounds as fluoride delivery system and may deliver $\mathrm{F}$ - ions more efficiently for caries prevention in patients suffering from xerostomia after radiation therapy.

\section{Conflict of interest}

\section{None declared}

\section{Acknowledgements}

The authors thank Ankica Tecic for her technical assistance.

This study was supported by the Croatian Ministry of Science and Education (grant for University institutional science funding).

The study was presented at $9^{\text {th }}$ Croatian Congress of Pharmacology with International Participation, Zagreb, Croatia (28 September 2019) gela u redestiliranoj vodi. Te su koncentracije gotovo tri puta niže od koncentracija $\mathrm{F}^{-}$iona u otopinama $\mathrm{NaF}$ gela u istim otapalima zbog nedostatka interakcija iona između aminofluorida i drugih iona prisutnih u otopinama.

Ograničenja ovog istraživanja odnose se na uzorke i metodologiju.

Metodologija se temeljila na razmjerno novom standardu ISO 19448:2018. Taj je standard trebao biti generička smjernica koja ne čini razliku između fluorida u spojevima. Metoda bi trebala biti prihvatljiva za analizu fluorida u vodenim otopinama svih fluoridiranih proizvoda za oralnu higijenu.

Modificirali smo standard ISO 19448:2018 i otopinama nismo dodali TISAB, što je moglo utjecati na mjerenje, kao što je već spomenuto.

U nedostatku dodatne validirane analitičke metode koja se koristi na istim uzorcima (npr., plinska kromatografija (22)) nije moguće u cijelosti procijeniti valjanost standarda ISO 19448:2018.

U studiji je upotrijebljen malen, nesistematičan i prikladan uzorak fluoridnih gelova, koristeći se samo jednim uzorkom svake vrste.

Bez pouzdanih i sveobuhvatnih podataka o sastavu fluoridnih gelova nije moguće ekstrapolirati njihovu učinkovitost na temelju sadržaja fluorida. No u ovom smo istraživanju promatrali ionske interakcije koje mogu utjecati na proces demineralizacije-remineralizacije in vivo.

\section{Zaključak}

Natrijev fluorid i aminofluoridi razlikuju se u mehanizmima dostave fluoridnih iona. Aminofluoridi ne ulaze u interakciju s drugim ionima u otopini, a oslobađanje $\mathrm{F}$ - iona iz natrijeva fluorida mijenja se ako se drugi ioni nalaze u istoj otopini. Nadalje, veća količina F- iona oslobađa se iz NaF-a u otopinama koje sadržavaju kloride, citrate i acetate. $S$ obzirom na to treba napomenuti da su aminofluoridi stabilniji spojevi za dostavu fluorida i mogu učinkovitije isporučiti Fione za prevenciju karijesa pacijentima koji pate od kserostomije nakon terapije zračenjem.

\section{Sukob interesa}

Autori nisu bili u sukobu interesa.

\section{Zahvale}

Autori zahvaljuju Ankici Tečić na pomoći u laboratoriju.

Rad je financiralo Ministarstvo znanosti i obrazovanja (namjensko višegodišnje institucijsko financiranje znanstvene djelatnosti, potpore Sveučilišta u Zagrebu).

Rezultati ovog istraživanja predstavljeni su na 9. Hrvatskom kongresu farmakologije s međunarodnim sudjelovanjem (Zagreb, Hrvatska, 28. rujna 2019.). 
Sažetak

Cilj: U istraživanju se željela odrediti koncentracija fluorida u različitim otapalima i usporediti je s deklariranom koncentracijom fluorida. Materijal i metode: Gel koji sadržava aminofluorid i natrijev fluorid uspoređen je s gelom samo s natrijevim fluoridom. Otapala korištena u ovom istraživanju bila su destilirana voda, redestilirana voda, voda iz slavine, 0,9-postotna otopina natrijeva klorida i umjetna slina. Količina fluoridnih iona (F) određena je fluor-selektivnom elektrodom. Korišteni su ANOVA i post hoc Tukeyjev test. Razina značajnosti bila je $\alpha=5 \%$. Rezultati: Razlike između otpuštanja $F$ iona u različitim otapalima bile su statistički značajne $(p<0,05)$. Koncentracija $F$ - iona izmjerena $u$ otopinama redistilirane vode obaju gelova bila je viša od deklariranih koncentracija. Zabilježena je značajna razlika u otpuštanju fluorida između otopina gela koje su sadržavale samo natrijev fluorid. Oslobađanje fluoridnih iona bilo je značajno različito u otopinama kombiniranoga fluoridnog gela. Zaključak: Aminofluoridi ne stupaju u interakciju s drugim ionima u otopini, a otpuštanje $F$ - iona iz natrijeva fluorida mijenja se kada su u istoj otopini i drugi ioni. Aminofluoridi učinkovitije dostavljaju F-ione za prevenciju karijesa.
Zaprimljen: 23. travnja 2020.

Prihvaćen: 1. lipnja 2020.

Adresa za dopisivanje doc. dr. sc. Kristina Peroš Sveučilište u Zagrebu, Stomatološki fakultet

Katedra za farmakologiju Šalata 11, 10 000 Zagreb, Hrvatska,

tel: +38514566957,

faks: +38514920049, peros@sfzg.hr

Ključne riječi

kariostatska sredstva; topikalni fluoridi; gelovi; natrijev fluorid; ion-selektivne elektrode; amin-fluorid

\section{References}

1. Fejerskov O, Kidd EAM, editors. Dental caries: the disease and its clinical management, 2nd ed. Oxford: Blackwell Munksgaard; 2008.

2. Ullah R, Zafar MS. Oral and dental delivery of fluoride: A review. Fluoride. 2015;48:195.

3. Buzalaf MAR. Fluoride and the Oral Environment. Basel; 2011.

4. Rosin-Grget K, Peros K, Sutej I, Basic K. The cariostatic mechanisms of fluoride. Acta Med Acad. 2013;42(2):179-188.

5. Li X, Wang J, Joiner A, Chang J. The remineralisation of enamel: a review of the literature. J Dent. 2014 Jun;42 Suppl 1:S12-20.

6. Eggert F, Neubert R. In vitro investigation of the liberation of fluoride ions from toothpaste compounds in a permeation model. Eur J Pharm Biopharm. 1999 Mar;47(2):169-73.

7. Eisbruch A, Ten Haken RK, Kim HM, Marsh LH, Ship JA. Dose, volu $\mathrm{me}$, and function relationships in parotid salivary glands following conformal and intensity-modulated irradiation of head and neck cancer. Int J Radiat Oncol Biol Phys. 1999 Oct 1;45(3):577-87.

8. Aguiar GP, Jham BC, Magalhaes CS, Sensi LG, Freire AR. A Review of the biological and clinical aspects of radiation caries. J Contemp Dent Pract. 2009 Jul 1;10(4):83-9.

9. Gupta N, Pal M, Rawat S et al. Radiation-induced dental caries, prevention and treatment - A systematic review. J Contemp Dent Pract. 2009 Jul 1;10(4):83-9.

10. Zandim DL, Tschoppe P, Sampaio JE, Kielbassa AM. Effect of saliva substitutes in combination with fluorides on remineralization of subsurface dentin lesions. Support Care Cancer. 2011;19(8):1143-1149.

11. Abdalla R, Niazy MA, Jamil WE, Hazzaa HA, Elbatouti AA. The role of fluoride and chlorhexidine in preserving hardness and mineralization of enamel and cementum after gamma irradiation. Support Care Cancer. 2011 Aug;19(8):1143-9.

12. Analysis of fluoride concentration in aqueous solutions by use of fluoride ion-selective electrode, ISO 19448:2018 Dentistry.
13. Carey CM. Focus on fluorides: update on the use of fluoride for the prevention of dental caries. J Evid Based Dent Pract. 2014 Jun;14 Suppl:95-102.

14. Cate JM ten, Buijs MJ, Miller CC, Exterkate RA. Elevated fluoride products enhance remineralization of advanced enamel lesions. Dent Res. 2008 Oct;87(10):943-7.

15. Loveren C. Toothpastes. Basel: S. Krager AG; 2013.

16. Fiket Z, Rozmaric M, Krmpotic M, Benedik L. Levels of major and trace elements, including rare earth elements, and 238U in Croatian tap waters. Environ Sci Pollut Res Int. 2015 May;22(9):6789. 99.

17. Martínez-Mier EA, Cury JA, Heilman JR, Katz BP, Levy SM, Li Y, Maguire A, et al. Development of gold standard ion-selective electrode-based methodsfor fluoride analysis. Caries Res. 2011;45(1):312.

18. Martínez-Mier EA, Soto-Rojas AE, Buckley CM, Margineda J, Ze ro DT. Evaluation of the direct and diffusion methods for the determination of fluoride content in table salt. Community Dent Health. 2009 Dec;26(4):204-10.

19. De Moor RJ, Martens LC, Verbeeck RM. Effect of a neutral citrate solution on the fluoride release of conventional restorative glass ionomer cements. Dent Mater. 2005 Apr;21(4):318-23.

20. Vrček D, Prpić-Mehičić G, Verzak Ž, Vrček J, Matijević J, Rošin Grget K. Fluoride Release from Hard Dental Tissue Restorative Materials. Acta Stomatol Croat. 2013;47(2):111-119.

21. Brzović-Rajić V, Miletić I, Gurgan S, Peroš K, Verzak Ž, IvaniševićMalčić A. Fluoride Release from Glass lonomer with Nano Filled Coat and Varnish. Acta Stomatol Croat. 2018 Dec;52(4):307-313.

22. Jordan RA, Markovich L, Gaengler P, Zimmer S. Total and free fluoride concentrations of African dentifrices marketed in West Africa. Oral Health Prev Dent. 2011;9(1):53-8. 